North of England, where he had lived for the last ten years; but for the members of his family and his intimate friends, more especially for one to whom he always showed the kind feeling of a brother, it will cast a shadow over what remains of life. ${ }^{1}$

L. Fletcher.

\title{
ROBERT HARRIS VALPY, J.P., F.G.S.
}

BorN SEPTBMBER 16, 1819.

Died Defember 18, 1904.

Mr. R. H. VALPY, whose death, in his 86th year, we regret to record, had been an active worker among the Devonian rocks of North Devon. Residing for portions of many years at Ilfracombe, he gathered together a rich collection of fossils from that neighbourhood, and his help was cordially acknowledged by Mr. Etheridge in the celebrated paper " On the Physical Structure of West Somerset and North Devon, and on the Palæontological Value of the Devonian. Rocks" (Quart. Journ. Geol. Soc., vol. xxiii, 1867, see pp. 605-8, etc.). Mr. Valpy himself never published much, and his little work entitled "Notes on the Geology of Ilfracombe and the Neighbourhood" was issued anonymously, by Twiss \& Sons, Ilfracombe. He was a man who seemed to shrink from publicity, and to prefer a quiet and retired country life. He was the only son of Capt. A. B. Valpy, R.N., of Combe Lodge, Blagdon, Somerset, and was born at Streatley in Berkshire. He was educated, first, under his relative, the eminent Dr. Richard Valpy, F.S.A., at the Reading Grammar School, and afterwards at Harrow and Balliol College, Oxford, and qualified in 1846 as J.P. for Berkshire. In 1849 he purchased the estate of Enborne Lodge, near Newbury, in Berkshire, and this was his principal home during the greater part of his life. There he was highly respected as "the good squire," and he lived to be the oldest magistrate in the county. ${ }^{2}$

When engaged in the re-survey of portions of the Mendip Hills in 1869 the present writer, together with Mr. Ussher, had the good fortune to meet Mr. Valpy at Blagdon. Every locality for fossils appeared familiar to $\mathrm{Mr}$. Valpy, who pointed out the occurrence of trilobites in the basement portion of the Lower Limestone Shales near Burrington, the occurrence of bone-beds in the Carboniferous Limestone, and the presence of Rhætic beds in a somewhat abnormal position in the vicinity of Blagdon. He also mentioned that he bad found striæ, which he considered might be of glacial origin, on blocks of Carboniferous Limestone in the Dolomitic Conglomerate. The information which he had acquired here, as elsewhere, by a very close study of the rocks, was ever generously placed at the service of others.

H. B. W.

1 Reprinted from the Mineralogical Magazine, October, 1904, vol. xiv, No. 63, pp. $61-64$.

i If not the founder, he was a member of the Old "Valpeian Club," which dined together annually in London to keep alive the memory of old Dr. Valpy-the author of Valpy's Latin Grammar, on which so many boys were brought up ! 